Journal of Association of Arab Universities For Tourism and Hospitality

Volume 15 - December 2018 - (special issue) Page : ( 10- 24 )

\title{
Depictions of Holding Animal Baskets in the Middle Kingdom Private Tombs
}

\author{
Walaa Mohamed Abdelhakim - Samar Mostafa Kamal \\ Tourist Guidance Department, Faculty of Tourism and Hotels, Minia University
}

\begin{abstract}
The ancient Egyptian artist depicted the animal in a variety of contexts and postures on the walls of the tombs. This paper focuses on depictions showing the animal in an indirect contact with its bearer. The animal was kept in a certain kind of basket which was commonly held by an individual, i,e. the basket was used as an intermediate tool between the animal and the bearer of the basket. Thus the study mainly circled around three elements; the animal, the basket, and the bearer. The suitable methodology that will be used to achieve the aim of the study is the descriptive and analytical one applied to the scenes of the Middle Kingdom private tombs (Beni Hassan, Meir, El Bersha, and Thebes). The study resulted in certain important points including; the main species of animals usually held in the basket; the context, in which the animal was kept in the basket (mainly for offering); the way, in the animal was depicted (young or grown up, with complete body or just apart that appears from the basket, in a profile or frontal representation); the form, the color, and the material of the basket containing the animal; and the individual holding the basket (usually male, or female), and the way he or she holds the basket, by hands, on shoulders, or even on the head.

Key Words: Animals, Baskets, Middle Kingdom, Private tombs.
\end{abstract}

\section{Introduction}

The Formal Egyptian art was practical and per formative, what was represented was believed to be enacted through the process of depiction, and therefore became real and a part of the daily routine as well. ${ }^{1}$ Representations were commonly encoded with symbols that were not necessarily transferable. Understanding the Ancient Egyptian codes often requires a deeper familiarity with the whole scene contexts, as interpretations vary and are not necessarily consistent. ${ }^{2}$

The ancient Egyptian figural art contributes to full understanding of some aspects of Egyptian cultural heritage never treated in the inscriptional material. The Middle Kingdom private tombs provide a particularly rich and well preserved record of art and daily routine of the ancient Egyptians. A detailed examination of the basket holding animals' depictions in the Middle Kingdom private tombs has the potential to yield much more information and truly enrich our knowledge of the period. ${ }^{3}$

Social and political changes that had occurred in the late Old Kingdom and First Intermediate Period, may have led to the emerge of the provincial governors in the Middle Kingdom. Domestic stability, external contacts especially with the Asiatics and long prosperous reigns combined to produce this flowering. In addition to sculpture and relief, Egyptian wall painting focusing on two-dimensional depictions and decorative art of the Middle Kingdom are creative, refined and technically of high quality. Egyptian wall painting was an elaborate code designed to maintain the surrounding environment through its reduction to certain elements. The private rock cut tombs of the provincial governors which date back to the Middle Kingdom expressed the status of the tomb owners. The tomb decoration features a wide range of social details that have so far not been extensively examined. ${ }^{4}$

The Middle Kingdom art is regarded as one of the most exciting and innovative of the ancient Egyptian periods. At the beginning artists attempted to resume working according to the styles of the Old Kingdom, but later on they set off in new directions and succeeded in producing some of the most sophisticated works that rank among the finest of Egyptian art. $^{5}$

The ancient Egyptian artist depicted the animal in a variety of contexts and postures on the walls of the tombs. This paper focuses on the depictions showing the animal in an indirect contact with its bearer. The animal was kept in a certain kind of basket which was commonly held by an individual. The variety of basket holding animals were traditionally put on the bearer's head, shoulder or even caught by hands. Depicting a man bearing on his shoulder a yoke with two large pots, or baskets, is a repeated subject in a different way in daily life scenes. The baskets were usually filled with fowls, animals or fish. The regular iconographic elements included daily life scenes of wild hunting, fishing, fowling, presenting offerings and other routine activities.

This paper aims to be an analytical and a descriptive study of the depictions of holding animal baskets in the Middle Kingdom private tombs, their different types of portrayal and meanings, and the paper main objectives are;

- $\quad$ To specify the main species of animals usually held in the basket.

- To outline the context of the wall scene, showing the animal kept in the basket.

- To establish the basic images of the basket containing the animal.

- To describe the figural portrayal of the animal holder.

\section{Results and Discussion}

The depiction of holding animal baskets was included in different contexts on the walls of the Old Kingdom tombs. These contexts comprise the following scenes (Table 1): 
Depictions of Holding Animal Baskets in the Middle Kingdom Private Tombs

Walaa Mohamed Abdelhakim - Samar Mostafa Kamal

Table (1)

Old Kingdom Contexts

\begin{tabular}{|c|c|c|c|}
\hline The Main scene & Marsh-related activities & & Desert-related activities \\
\hline $\begin{array}{l}\text { The theme included } \\
\text { in the scene }\end{array}$ & Fish-bearer(s) & Caught marsh birds in cages. & $\begin{array}{l}\text { Hunters returning from the } \\
\text { desert with animals. }\end{array}$ \\
\hline $\begin{array}{l}\text { The drawing of } \\
\text { holding animal } \\
\text { baskets }\end{array}$ & & & \\
\hline $\begin{array}{l}\text { The tombs in which } \\
\text { the theme is found }\end{array}$ & $\begin{array}{l}11 \text { tombs at Giza, } 25 \text { at Saqqara, } 2 \text { at } \\
\text { Nag' el-Deir, and just one theme } \\
\text { found in each cemetery at Abusir, } \\
\text { Dahshur, Maidum, Deshasha, Deir } \\
\text { el-Gebrawi, Meir, el-Hawawish, el- } \\
\text { Hagarsa, Dendera, and el-Khokha. }\end{array}$ & $\begin{array}{l}8 \text { tombs at Giza, } 8 \text { at Saqqara, and } \\
\text { just one theme found in each } \\
\text { cemetery at Zawyet el-Maiyetin, } \\
\text { Sheikh Said, Deir el-Gebrawi, el- } \\
\text { Hammamiya, and el-Hawawish. }\end{array}$ & $\begin{array}{l}2 \text { tombs at Giza, } 6 \text { at Saqqara, } \\
\text { and one in each cemetery at } \\
\text { Meidum, Deir el-Gebrawi, and } \\
\text { el-Qasr wa-'l-Saiyad. }\end{array}$ \\
\hline
\end{tabular}

Source: designed by the researcher

The following table, shows the main contexts for the Middle Kingdom scenes that include the depiction of holding animal baskets. They are mainly three; marsh-related activities, desert-related activities, and offering processions.

Table (2)

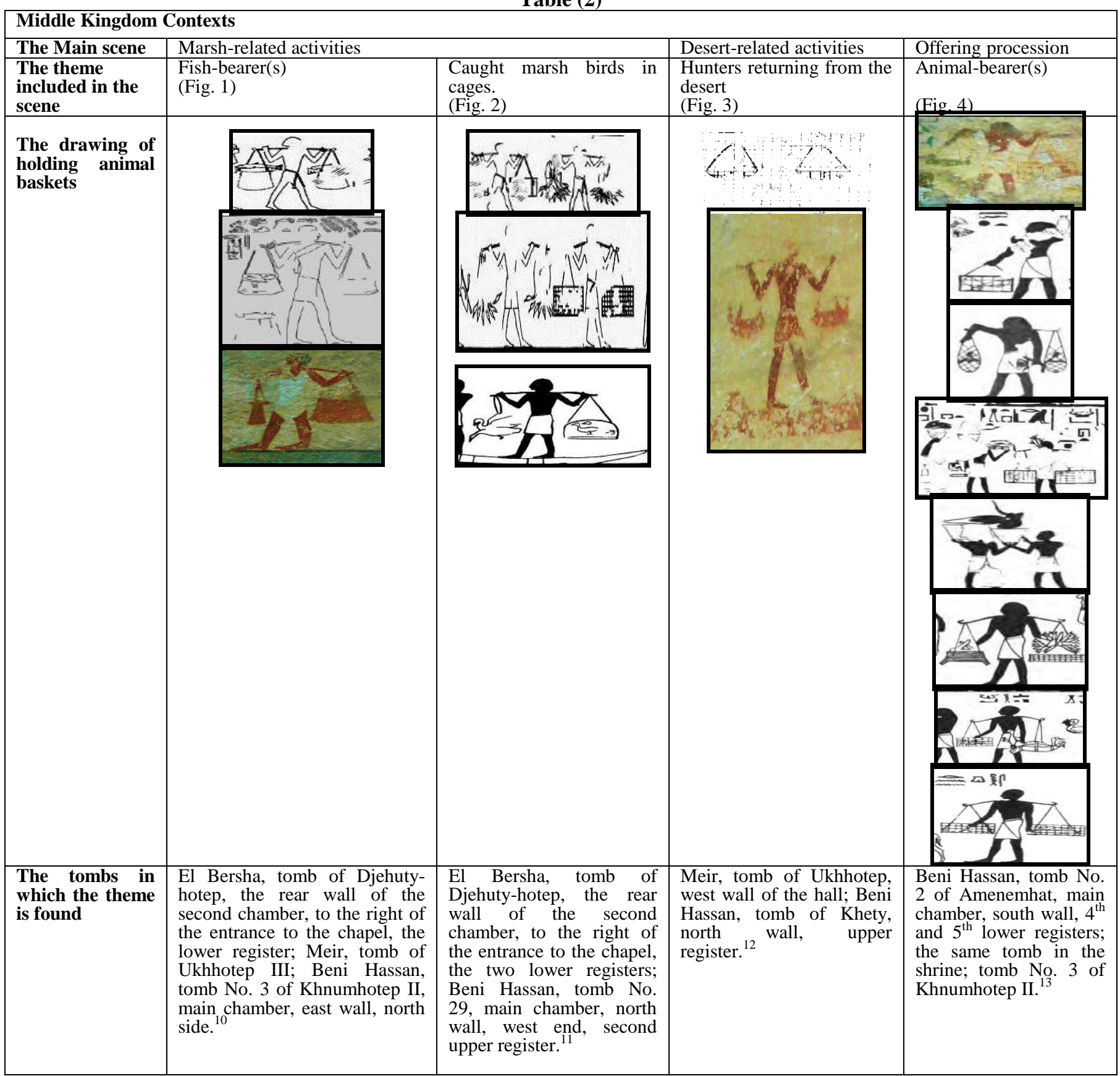

Source: designed by the researcher 


\section{Animals held in baskets}

Certain species of baskets animals appeared in the Middle Kingdom depiction. These animals include three main species that walk (gazelle, hare, and bull), fly (birds), and swim (fish).

The Gazelle

The iconography of gazelle " $g h s$ " in desert hunting contexts seems to be related to rebirth and fertility issues. The gazeles was regarded also as luxury food and an essential part of the offering bearers' processions as early as the Old Kingdom. ${ }^{4}$ Dorcas gazelles too have been classified "hiders" as protecting their young among shrubs, as explained by group of infant gazelles depicted on the tomb wall. They were held in baskets by bearers either in the desert hunting contexts or in the offering processions to the tomb owner. ${ }^{15}$

The depiction of holding gazelle basket, (table 3), is mainly found on the walls of the Old Kingdom mastabas. There are only two examples of the animal in this depiction that dates back to the Middle Kingdom . ${ }^{\circ}$

Table (3)

\begin{tabular}{|l|l|l|l|l|}
\hline $\begin{array}{l}\text { The animal in } \\
\text { the basket }\end{array}$ & $\begin{array}{l}\text { The drawing in the } \\
\text { theme }\end{array}$ & $\begin{array}{l}\text { The way of depiction } \\
\text { the species of } \\
\text { animal } \\
\text { the theme }\end{array}$ & $\begin{array}{l}\text { The tomb in which } \\
\text { depiction } \\
\text { is } \\
\text { found }\end{array}$ \\
\hline Gazelle & $\begin{array}{l}\text { One young gazelle appeared from } \\
\text { the top of the basket recumbent, } \\
\text { with the head turned back in a } \\
\text { direction opposite to that of the } \\
\text { individual holding the basket. } \\
\text { In one basket a gazelle appears } \\
\text { sinking his mouth inside it. }\end{array}$ & $\begin{array}{l}\text { Deir, tomb of } \\
\text { Ukhhotep, west wall } \\
\text { of the hall. }\end{array}$ \\
\hline Gazelle & $\begin{array}{l}\text { A young gazelle was put upside } \\
\text { down with only the legs which } \\
\text { appeared from the top of the basket. }\end{array}$ & Unknown & $\begin{array}{l}\text { Beni Hassan, tomb } \\
\text { of Khety, north } \\
\text { wall, } \\
\text { register. }\end{array}$ \\
\hline
\end{tabular}

\section{The Hare}

\section{Source: designed by the researcher}

Hare was mostly found at Upper Egyptian sites as early as the Pre-dynastic Period. This animal inhabited deserts, as long as there was sufficient vegetation for food, as well as in cultivated fields and wadi floors. ${ }^{19}$

The Egyptian species of hare frequently represented on the wall paintings is marked with black speckles. It is known as (the Cape hare) (Lepus capensis). It was chased by the help of greyhounds. It was usually seized alive and kept either in baskets, bags, or cages along with the fruits of the field and harvest delivered by bearers in offering processions (table 4).

\begin{tabular}{|c|c|c|c|c|}
\hline \multicolumn{5}{|c|}{ Table (4) } \\
\hline $\begin{array}{l}\text { The animal in the } \\
\text { basket }\end{array}$ & $\begin{array}{l}\text { The drawing in the } \\
\text { theme }\end{array}$ & The way of depiction & $\begin{array}{l}\text { The species of the } \\
\text { animal in the theme }\end{array}$ & $\begin{array}{l}\text { The tomb in which } \\
\text { the depiction is } \\
\text { found }\end{array}$ \\
\hline Hare & 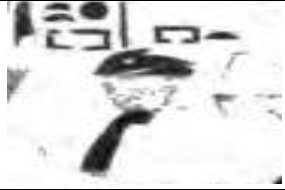 & $\begin{array}{l}\text { Recumbent in profile } \\
\text { on the top of the } \\
\text { basket; with the head } \\
\text { in a direction opposite } \\
\text { to the individual who } \\
\text { holds the basket. }\end{array}$ & $\begin{array}{l}\text { The Egyptian } \\
\text { Cape hare with the } \\
\text { body colored in black. }\end{array}$ & $\begin{array}{l}\text { Beni Hassan, tomb } \\
\text { No. } 2 \text { of Amenemhat, } \\
\text { shrine, north-west and } \\
\text { north walls. }\end{array}$ \\
\hline & 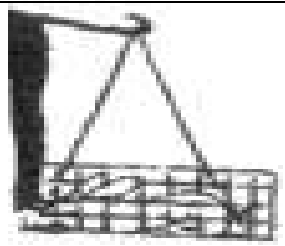 & $\begin{array}{l}\text { Two hares recumbent } \\
\text { in profile inside a } \\
\text { basket having the } \\
\text { form of a cage. The } \\
\text { heads here are in the } \\
\text { same direction of the } \\
\text { individual holding the } \\
\text { basket. }\end{array}$ & $\begin{array}{l}\text { The Egyptian } \\
\text { Cape hare with the } \\
\text { body colored in white. }\end{array}$ & $\begin{array}{l}\text { Beni Hassan, tomb } \\
\text { No. } 3 \text { of Khnumhotep } \\
\text { II. }\end{array}$ \\
\hline
\end{tabular}

\section{The Bull}

(Source: designed by the researcher

The Ancient Egyptians usually preferred the long-horned bull in their sacrifice. The bull appeared only once in the Middle Kingdom depiction of holding animal baskets. Just the head of the animal is shown on the top of a basket held by an offering bearer in a scene found in the shrine of tomb No. 2 of Amenemhat at Beni Hassan. The head of the bull appears with its right long horn, while the left one seems to be winkled out. ${ }^{2 \dot{3}}$

The ancient Egyptians operated on the horns of bulls in order to improve their shape and to distinguish the bull devoted for sacrifice. This improvement was not only physical in appearance but also produced a practical change, preventing these animals from bullfighting during the mating season. The process of horn improvement starts very early when the calves devoted for slaughter and religious rituals are small, and during the active growth of the horns. This process spread in ancient Egypt from the Prehistoric Period and continued till the end of the ancient Egyptian history.

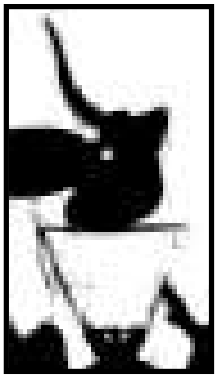
It is still practised in some modern African tribes. ${ }^{24}$

\section{The Bird}

The birds that were mainly included in the Middle Kingdom depiction of holding animal baskets are ducks (table 5). Among the several species of ducks that appeared early in the representations of the Old Kingdom scenes is the (European Wigeon). It was a popular hieroglyphic sign in the Middle Kingdom tombs of Beni Hassan. It is identified with certain characteristic male features; reddish-brown head, neck, upper breast, and primary feathers; green back, flank, feet, and bill; white forehead, belly, a band on the wing; and a black terminal band on the tail. ${ }^{25}$ 
The other species of ducks found in the depiction of holding animal baskets is the Pintail. It is one of waterfowl species that is frequently depicted in the ancient Egyptian art and hieroglyphs. The earliest representation of the Pintail in hieroglyphs dates back to the $2^{\text {nd }}$ Dynasty, on a niche stela from Saqqara. It is identified with certain features; the slender build, elongated and thin neck, short legs, and elongated pointed central tail feathers. ${ }^{26}$

Table (5)

\begin{tabular}{|c|c|c|c|c|}
\hline The animal in the basket & $\begin{array}{l}\text { The drawing in the } \\
\text { theme }\end{array}$ & The way of depiction & $\begin{array}{l}\text { The species of the } \\
\text { animal in the } \\
\text { theme }\end{array}$ & $\begin{array}{l}\text { The tomb in } \\
\text { which } \\
\text { depiction the } \\
\text { found }\end{array}$ \\
\hline Bird & & $\begin{array}{l}\text { Usually facing toward the left, } \\
\text { with the right leg placed } \\
\text { forward of the left. In case of } \\
\text { the presence of anather one or } \\
\text { any different species of birds, } \\
\text { they were arranged in opposite } \\
\text { directions. }\end{array}$ & 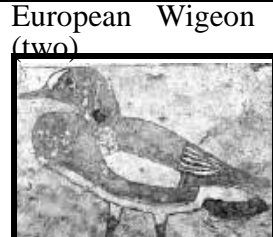 & $\begin{array}{l}\text { Beni Hassan, } \\
\text { tomb No. } 3 \text { of } \\
\text { Khnumhotep } \\
\text { II. }{ }^{27}\end{array}$ \\
\hline Bird & & $\begin{array}{l}\text { Facing toward the left, with one } \\
\text { leg forward of the other. It is } \\
\text { noticed in the drawing that two } \\
\text { birds of the same species were } \\
\text { placed together side by side in } \\
\text { a direction opposite to the other } \\
\text { different species in the same } \\
\text { cage. }\end{array}$ & $\begin{array}{l}\text { The Pintail (two) } \\
\text { and a single } \\
\text { European Wigeon }\end{array}$ & $\begin{array}{l}\text { Beni Hassan, } \\
\text { tomb No. } 2 \text { of } \\
\text { Amenemhat, } \\
\text { main chamber, } \\
\text { south wall, the } \\
4^{\text {th }} \text { register. }\end{array}$ \\
\hline
\end{tabular}

\section{The Fish}

\section{Source: designed by the researcher}

According to recent studies, the Nile water houses about 65 fish species. 30 of them can be recognized in the ancient Egyptian scenes. Realistic images of fish species appeared on the walls of the Old Kingdom Private tombs, mainly at Saqqara. The representations of fish and fishing were revived during the Middle Kingdom (table 6). ${ }^{29}$ It was noticed that fish did not appear on any of the offering tables as part of the eternity offerings at Beni Hassan tombs and instead suggested was that the fish were perhaps intended for the servants or pets of the deceased, ${ }^{30}$

Table (6)

\begin{tabular}{|c|c|c|c|c|}
\hline \\
\hline The animal in the basket & $\begin{array}{l}\text { The drawing in the } \\
\text { theme }\end{array}$ & The way of depiction & $\begin{array}{l}\text { The species of the } \\
\text { animal in the theme }\end{array}$ & $\begin{array}{l}\text { The tomb in which } \\
\text { the depiction is } \\
\text { found }\end{array}$ \\
\hline Fish & & $\begin{array}{l}\text { Just two fish species } \\
\text { appeared from the top of } \\
\text { the basket (one is lean } \\
\text { and the other is fatty). } \\
\text { They are represented in } \\
\text { a profile showing the fin } \\
\text { and tail. It seems that } \\
\text { the basket is entirely } \\
\text { full, as the tail of one of } \\
\text { the two species } \\
\text { appeared outside the } \\
\text { basket. }\end{array}$ & $\begin{array}{l}\text { The elephant fish } \\
\text { (Mormvrus caschive) } \\
\text { Nile tilapia } \\
\text { (Oreochromis } \\
\text { niloticus). }\end{array}$ & $\begin{array}{l}\text { Meir, tomb of } \\
\text { Ukhhotep III. }^{31}\end{array}$ \\
\hline \multirow[t]{2}{*}{ Fish } & & $\begin{array}{l}\text { Two fish of the same } \\
\text { species appeared on the } \\
\text { top of the basket } \\
\text { inversely; the head of } \\
\text { one beside the tail of the } \\
\text { other in symmetry. }\end{array}$ & $\begin{array}{l}\text { Elephant fish } \\
\text { (Hvperopisus bebe) }\end{array}$ & $\begin{array}{l}\text { El Bersha, tomb of } \\
\text { Djehuty-hotep, the } \\
\text { rear wall of the } \\
\text { second chamber, to } \\
\text { the right of the } \\
\text { entrance to the chapel, } \\
\text { the lower register. }\end{array}$ \\
\hline & & $\begin{array}{l}\text { A number of fish, most } \\
\text { probably five, were } \\
\text { placed vertically inside } \\
\text { the basket. Only tails } \\
\text { appear from the top, so } \\
\text { the exact species of fish } \\
\text { is difficult to be } \\
\text { identified. }\end{array}$ & Unknown & $\begin{array}{l}\text { Beni Hassan, tomb } \\
\text { No. } 3 \text { of Khnumhotep } \\
\text { II, main chamber, east } \\
\text { wall, north side. }\end{array}$ \\
\hline
\end{tabular}

\section{Source: designed by the researcher}

The two fish species, mentioned above in the table, played a role in religion and mythology of ancient Egypt. The Nile tilapia was a symbol of fertility and rebirth, while the Elephant fish was a symbol of goddess Hathor at Oxyrhynchus and other places. ${ }^{34}$

The basket containing the animal

The basket in general is defined as an object made of plant parts of limited length often with a shape specific to that particular plant part. ${ }^{35}$ It was usually made of the leaves of palm trees like bags, couches, brushes, and fly-traps (table 7). ${ }^{36}$ 
Journal of Association of Arab Universities For Tourism and Hospitality

Volume 15 - December 2018 - (special issue) Page : ( 10- 24)

\begin{tabular}{|c|c|c|}
\hline \multicolumn{3}{|c|}{ Table (7) } \\
\hline The form of the basket & $\begin{array}{l}\text { The drawing in } \\
\text { the theme }\end{array}$ & The tomb in which the form is found \\
\hline $\begin{array}{l}\text { A cage that is defined as a structure of crossed } \\
\text { bars, in which birds or other animals are confined. } \\
\text { The cage here is square with the bars appearing as } \\
4 \text { crossed vertical and horizontal lines. }\end{array}$ & & $\begin{array}{l}\text { Beni Hassan, tomb No. } 2 \text { of Amenemhat, main } \\
\text { chamber, south wall, east end; tomb No. } 3 \text { of } \\
\text { Khnumhotep II. }{ }^{37}\end{array}$ \\
\hline $\begin{array}{l}\text { A rectangular cage with a number of vertical bars } \\
\text { (8). }\end{array}$ & & $\begin{array}{l}\text { Beni Hassan, tomb No. } 2 \text { of Amenemhat, shrine; } \\
\text { tomb No. } 3 \text { of Khnumhotep II; Bersha, tomb of } \\
\text { Djehuty-hotep, the rear wall of the second } \\
\text { chamber, the lower register. }\end{array}$ \\
\hline $\begin{array}{l}\text { A cage in the shape of inverted bowl with a } \\
\text { straight double lined base and a semicircular top } \\
\text { similar to the round topped stela. It is the same like } \\
\text { the modern birdcage (a cage for pet birds typically } \\
\text { made of wire or cane). }\end{array}$ & & $\begin{array}{l}\text { Beni Hassan, tomb No. } 29 \text {, main chamber, north } \\
\text { wall, west end, second upper register. }{ }^{39}\end{array}$ \\
\hline Mesh shaped bag made of a network of thread. & & $\begin{array}{l}\text { Beni Hassan, tomb No. } 2 \text { of Amenemhat, main } \\
\text { chamber, south wall, east end. } 40\end{array}$ \\
\hline Inverted rhomboid shaped basket. & & $\begin{array}{l}\text { Beni Hassan, tomb No. } 2 \text { of Amenemhat, } \\
\text { shrine. }\end{array}$ \\
\hline Bowl shaped basket. & & $\begin{array}{l}\text { Meir, tomb of Ukhhotep, hall, } \text { north wall; Beni } \\
\text { Hassan, tomb No. } 17 \text { of Khety. }{ }_{42}\end{array}$ \\
\hline $\begin{array}{l}\text { Bag seems to be of burlap that is defined as coarse } \\
\text { canvas woven from jute, hemp, or a similar fiber, } \\
\text { used especially for sacking. }\end{array}$ & & $\begin{array}{l}\text { Meir, tomb of Ukhhotep III; El Bersha, tomb of } \\
\text { Djehuty-hotep, the rear wall of the second } \\
\text { chamber, to the right of the entrance to the } \\
\text { chapel, the lower register; Beni Hassan, tomb No. } \\
3 \text { of Khnumhotep II, main chamber, east wall, } \\
\text { north side. }\end{array}$ \\
\hline $\begin{array}{l}\text { A basket with a shape similar to the small backless } \\
\text { chair with two inclined short legs. }\end{array}$ & & Beni Hassan, tomb No. 3 of Khnumhotep II. ${ }^{44}$ \\
\hline
\end{tabular}

Source: designed by the researcher

The yoke bearing two baskets

The idea of depicting an individual bearing on his shoulder a yoke or pole with two baskets came originally from the depictions of water carrier represented sporadically in various daily life scenes of the private tombs, but instead of the baskets used were large pots, jars, or vessels. ${ }^{4}$

Generally the yoke is a piece of wood, metal or other material, with the edges usually curved or bent back at an angle, for catching or hanging things on. The following table shows different shapes for the yoke that appeared in the depiction of holding animal baskets.

Table (8)

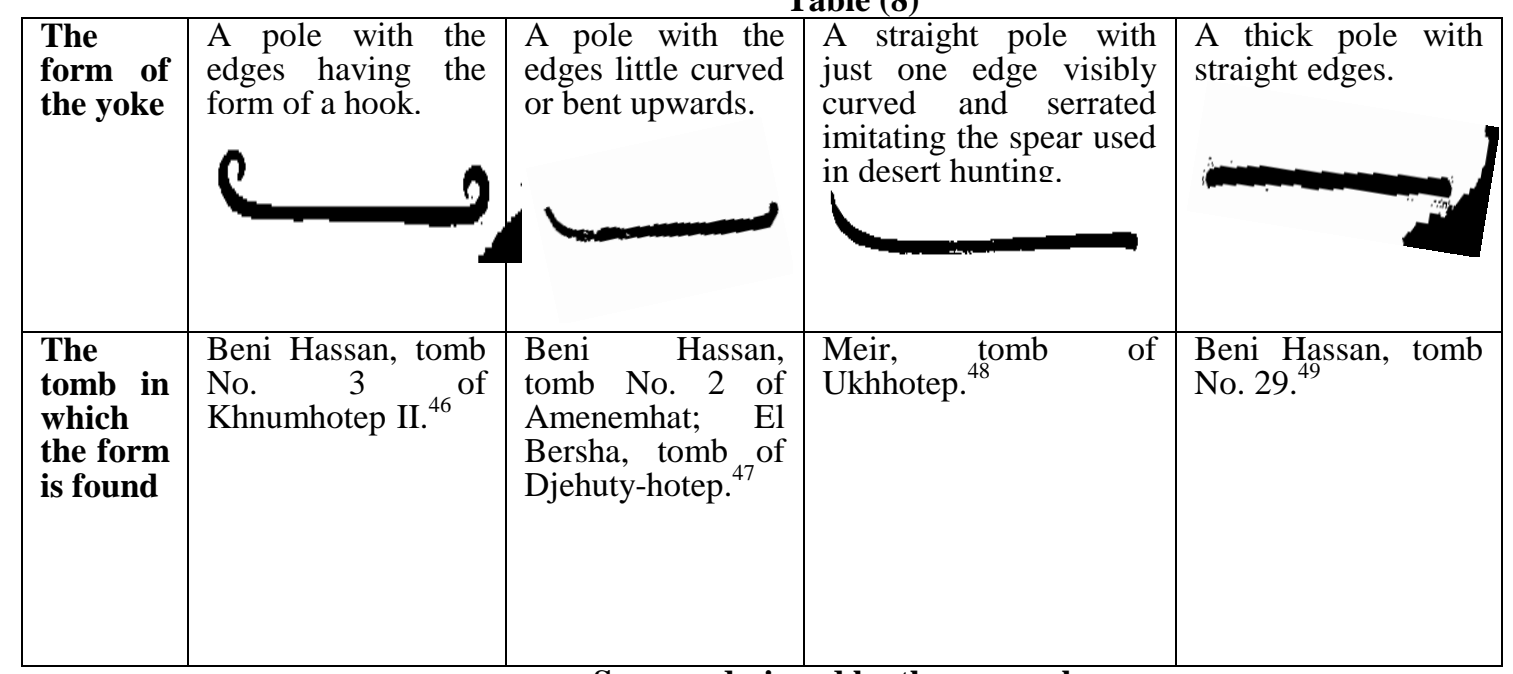

Source: designed by the researcher 
The portrayals of the individual holding animal basket

The depiction of holding animal baskets in all the Middle Kingdom scenes usually shows individuals holding the basket with certain characteristic features;

- Standing in a profile, with the torso in a frontal view, and one leg forward.

- Looking to one direction either left or right according to the place, where the deceased owner of the tomb is seated or standing.

- The body is painted with the traditional reddish brown color.

- Wearing a short wig that reaches the shoulders, or represented with his real short cut hair.

- Wearing usually a white short kilt that slightly touches the knees.

- All of the individuals holding the basket are males with the previously mentioned features, except for a unique example in tomb No. 2 of Amenemhat at Beni Hassan for a female holding the basket above her head. She stands in profile, wears a long wig hung on her back, and is dressed in a long tight garment. ${ }^{50}$

The main feature that differs from one individual to another is the posture of the hand that holds the basket. In case of bearing a yoke or a pole with two baskets on the shoulder, there are four

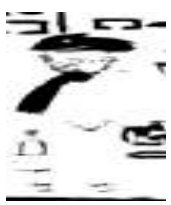
postures for the arms and hands (table 9);

Table (9)

Bending the arms downwards and holding the yoke with both hands. The fingers appear bending toward the palm around the yoke and tightly hold either the yoke only or together with the rope attached to the basket. In case of holding the yoke with the rope, the arm is bent across the rope. The empty space between the yoke

\begin{tabular}{l} 
and the bent arm forms a geometric shape that resembles an inverted triangle. \\
$\begin{array}{l}\text { One arm (the left one) is bent downwards and holds only the yoke with a tightly fist } \\
\text { beside the rope surrounding the edge of the yoke. The other arm (the right one) is } \\
\text { bent upwards across the yoke with an open hand placed on the rope. }\end{array}$ \\
$\begin{array}{l}\text { One arm (the left one) is straight between the body and the basket hanging from the } \\
\text { rope surrounding the edge of the yoke. The hand with its fist as closed on a small } \\
\text { offering. The other arm (the right one) is bent upwards across the yoke with an open } \\
\text { hand placed on the rope. }\end{array}$ \\
\hline $\begin{array}{l}\text { One arm (the left one) is straight between the body and the basket. The hand either } \\
\text { open or with a closed fist on a small offering. The other arm is slightly away from } \\
\text { the body touching the rope with the hand placed open on the basket. }\end{array}$
\end{tabular}

\section{Source: designed by the researcher}

In case of holding one basket containing the animal, there are just three themes. One of them is the previously mentioned unique example of the female placing the basket over her head. ${ }^{55}$ The individuals in the other two scenes are either holding the rope attached to the basket with a tightly fist alongside the body, (Beni Hassan, tomb No. 2 of Amenemhat, main chamber, south wall, east end), ${ }^{56}$ or bending the arm upwards and lifting the basket from its base by an open hand alongside the shoulder (Beni Hassan, tomb No. 2 of Amenemhat, shrine).

\section{The clothes of the individuals}

The dress that was usually worn by the individuals in the theme is the short kilt painted white. The kilt is usually wrapped, left over right or clockwise from the point of view of the wearer. This was originally the traditional royal fold that was a characteristic feature exclusive for the kings during the

Old Kingdom, while the fold of the private kilt was wrapped in an opposite direction. The fashion of the royal fold was already adapted by the high officials in the early $11^{\text {th }}$ Dynasty, and became more frequent in the $12^{\text {th }}$ Dynasty. It was almost the rule by the Second Intermediate Period. ${ }^{58}$

The kilt is provided with usual thin belt. The kilt in the theme of Meir slightly differs from the standard one in the other themes. The edge of the kilt fold is drooping from the back and appears

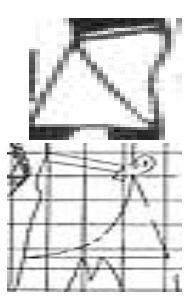
between the legs like a small tail. The thin belt of the kilt is tied in the middle forming a loop.

In El Bersha themes that are all included in the context of marsh- related activities, the two ends of the belt of the kilt appear with unconventional elongation, hanging down, crossing the edge of the kilt, and gently touch the knee. $^{60}$

A distinctive item of cloth appeared in another theme of Meir, which is (the sash). It is hung across one shoulder of the individual and tied around the body with the ends left hanging loose. In the Middle Kingdom tomb decoration, such sash was worn by both the elite and non-elite, but in different ways, styles, and colors, to maintain purity and cleanliness. Laborers, who are usually represented in outdoor settings preforming activities closer to physical labor, such as attending the tomb owner fishing and fowling, observing the livestock count, and overseeing funerary boats, are usually shown wearing sashes made of white linen in order to absorb sweat and wipe away dirts. ${ }^{61}$

The fishing theme on the eastern wall of the main chamber in tomb No. 3 of Khnumhotep II at Beni Hassan that is included in the scenes of marsh-related activities shows the fish bearer wearing a cloth completely differing from the usual dress worn by the individuals in the depiction of holding animal baskets. He appears with a proper white sleeveless garment with a drooping edge in the middle
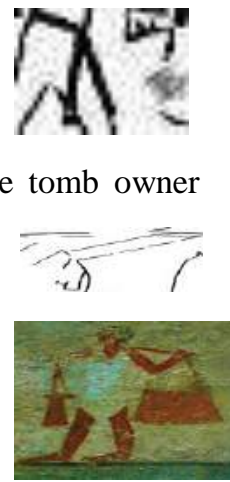
above the knees. It seems that this style of garment was exclusive for the fishers, as the scene shows all the individuals engaged in fishing dressed in the same cloth. ${ }^{62}$

\section{Conclusion}

The selected scenes are characterized by a sense of movement and liveliness and almost all the figures are represented in the moment of performance. This was difficult to occur in the strictly conventional funerary scenes.

The depictions of holding animal baskets were not stereotype scenes. Tomb depictions were revealing the diversification of scene types in the Middle Kingdom tombs, including certain issues including the main species of animals usually held in the basket; the context, in which the animal was kept in the basket; the way, the animal was depicted (young or grown up, with all the body or just apart that appears from the basket, in profile or frontal representation); the form, the color, and the material of the basket and the individual holding the basket (male, or female), and the way he or she holds the basket by hands, on shoulders, or even on the head.

Animals of the investigated scenes were traditionally depicted in profile, and like human representations, animals in striding position were rendered with the inner leg in advance. Birds were also depicted in profile, regardless of their tails and wings which were normally shown in a frontal view. Their wings were closed or outstretched in a very realistic manner.

The skill of the artist in representing small birds inside the cage; sometimes the beak of certain species of bird is seen out of the lines of the cage, as in the theme of Khnumhotep II.

The following table sums up the main characteristic features of the theme (table 10);

Table (10)

\begin{tabular}{|c|c|c|c|c|c|}
\hline & Beni Hassan & Meir & El Bersha & Thebes \\
\hline \multicolumn{2}{|c|}{ Total number of themes } & 12 & 2 & 2 & \multirow{9}{*}{$\begin{array}{l}\text { No } \\
\text { themes } \\
\text { for the } \\
\text { depiction } \\
\text { of } \\
\text { holding } \\
\text { animal } \\
\text { baskets }\end{array}$} \\
\hline \multicolumn{2}{|l|}{ The tombs } & $\begin{array}{l}- \text { tomb No. } 2 \text { of } \\
\text { Amenemhat } \\
\text { (6 themes). } \\
-\quad \text { tomb No. } 3 \text { of } \\
\text { Khnumhotep II } \\
\text { ( } 4 \text { themes) } \\
\text { - tomb No. } 17 \text { of Khety } \\
\text { (one theme) } \\
\text { - tomb No. } 29 \\
\text { (one theme) }\end{array}$ & $\begin{array}{l}\text { Tomb of } \\
\text { Ukhhotep III. }\end{array}$ & $\begin{array}{l}\text { Tomb of } \\
\text { Djehuty- } \\
\text { hotep. }\end{array}$ & \\
\hline \multirow[t]{3}{*}{$\begin{array}{l}\text { The context of the } \\
\text { scenes }\end{array}$} & $\begin{array}{l}\text { Marsh- } \\
\text { related } \\
\text { activities }\end{array}$ & $\begin{array}{l}\sqrt{ } \\
(2 \text { themes; tomb of } \\
\text { Khnumhotep II, N0. } 3 \text {, } \\
\text { and tomb No. } 29 \text { of } \\
\text { Baquet I) }\end{array}$ & $\sqrt{ }$ & $\sqrt{ }$ & \\
\hline & $\begin{array}{l}\text { Desert- } \\
\text { related } \\
\text { activities }\end{array}$ & $\begin{array}{l}\sqrt{ } \\
\text { (one theme, tomb No. } 17 \\
\text { of Khety) }\end{array}$ & $\sqrt{ }$ & & \\
\hline & $\begin{array}{l}\text { Offering } \\
\text { procession }\end{array}$ & $\begin{array}{l}\sqrt{ } \\
(9 \text { themes; tombs of } \\
\text { Amenemhat (6), and } \\
\text { Khnumhotep II (3)) }\end{array}$ & & & \\
\hline \multicolumn{2}{|l|}{ The animals } & $\begin{array}{l}\text { Gazelle, hare, bull, bird } \\
\text { (European Wigeon, and } \\
\text { Pintail), fish (unknown } \\
\text { species) }\end{array}$ & $\begin{array}{l}\text { Gazelle, fish } \\
\text { (The elephant } \\
\text { fish, and Nile } \\
\text { tilapia) }\end{array}$ & $\begin{array}{l}\text { Bird } \\
\text { (unknown } \\
\text { species), fish } \\
\text { (Elephant } \\
\text { fish) }\end{array}$ & \\
\hline \multirow[t]{2}{*}{$\begin{array}{l}\text { The number of } \\
\text { baskets }\end{array}$} & $\begin{array}{lr}\text { A } & \text { yoke } \\
\text { with } & 2 \\
\text { baskets } & \end{array}$ & $\sqrt{ }(9$ themes $)$ & $\sqrt{ }$ & $\sqrt{ }$ & \\
\hline & One basket & $\sqrt{ }(3$ themes $)$ & & & \\
\hline \multicolumn{2}{|l|}{ The style of basket } & $\begin{array}{l}\text { Square cage, rectangular } \\
\text { cage, an inverted bowl } \\
\text { cage, Mesh shaped bag, } \\
\text { Inverted rhomboid shaped } \\
\text { basket, Burlap bag, a } \\
\text { basket of small backless } \\
\text { chair shape. }\end{array}$ & $\begin{array}{ll}\text { Bowl } & \text { shaped } \\
\text { basket, } & \text { Burlap } \\
\text { bag. } & \end{array}$ & $\begin{array}{l}\text { Rectangular } \\
\text { cage, Burlap } \\
\text { bag. }\end{array}$ & \\
\hline
\end{tabular}

Source: designed by the researcher 
According to table, there are certain points to be revealed;

- The Middle Kingdom tombs including the depiction of holding animal baskets are located in 3 Middle Kingdom burials; Beni Hassan, Meir, and El Bersha.

- The number of these tombs is 6; 4 in Beni Hassan, one in Meir, and one in El Bersha.

- The total number of the themes representing the depiction of holding animal baskets is 16 . The largest number of the themes is found in the tombs of Beni Hassan (12), mainly in the two tombs of Amenemhat and Khnumhotep II.

- There ase three main contexts for the depiction of holding animal baskets; marsh-related activities, desertrelated activities, and offering processions. The context of offering procession includes the largest number of themes (9 themes). It is only found in the tombs of Beni Hassan (tombs of Amenemhat and Khnumhotep II).

- The three Middle Kingdom burials of Beni Hassan, Meir, and El Bersha share the same context of marshrelated activities, where the depiction of holding fish baskets is found. The fish was only preserved in a specific type of basket (the Burlap bag). This kind of basket is considered to be a material that breathes helping in preserving fish when ice is not available, as fish will spoil quickly without air circulation.

- Just two themes are included in the context of desert-related activities; one in the tomb of Khety at Beni Hassan, and the other in the tomb of Ukhhotep at Meir. Both the themes share the same wild animal (the gazelle) placed in the same shape of basket (the Bowl shaped basket), but differ in the way of representing the animal.

- The themes of Beni Hassan tombs that are mainly included in the context of offering procession are distinguished by the diversity of the species of animals (hare, bull, fish and bird, either European Wigeon or Pintail), and the shapes of baskets.

- All the themes including the depiction of holding animal baskets in the tombs of Beni Hassan, Meir, and El Bersha presented the individual holding two baskets by means of a yoke carried on his shoulders, except is examples found in Beni Hassan tombs, where just one basket is held. In the case of two baskets, it is not necessary to be of the same shape or even to contain the same species of animal. This variance is only found in the themes of Beni Hassan.

- The three styles of basket; the square cage, the rectangular cage, and the inverted bowl cage were only used to preserve birds. Just one case was found in the tomb of Khnumhotep II at Beni Hassan for a basket in the shape of a rectangular cage including small species of animals (the hare). This could mean that the cage sometimes was used for keeping animals of small sizes like hare.

- The rope used as a mediator element between the individual and the basket is attached either to the top edge of the basket or to the lower corners of the basket; The latter is only found in the rectangular cage.

- Animals of different species were not placed together in the same basket, except for fish and birds. In this case the different species were arranged in opposite directions inside the basket. as found in the tombs of Beni Hassan.

- The depictions of holding two baskets by means of a yoke show different shapes for the yoke. It seems that the most suitable one in the case of the heavy- weight baskets is the shape of the pole with the edges having the form of a hook in order to keep the rope attached to the basket.

Unique themes for the depiction of holding animal baskets;

- The sketch theme in the tomb of Ukhhotep at Meir that represents a hunter returning from the desert with two Basket young recumbent gazelles carried by means of a yoke on his shoulder.

- The desert hunting theme in the tomb of Khety at Beni Hassan shows a depiction of holding gazelle basket. The young gazelle was put upside down with only the legs appearing from the top of the basket.

- The offering theme in the shrine of the tomb of Amenemhat at Beni Hassan shows only the head of one long horned bull on the top of a basket held by an offering bearer.

- The unique styles of basket appeared once in the tombs of Beni Hassan. The cage is in the shape of an inverted bowl in tomb No. 29, the Mesh shaped bag in the tomb No. 2 of Amenemhat, and the basket in the shape of small backless chair in the tomb No. 3 of Khnumhotep II.

- The unique theme is found in the tomb of Amenemhat at Beni Hassan for a female holding a basket that includes a hare above her head.

- The unique style of the dress is that worn by the fish bearer in tomb No. 3 of Khnumhotep at Beni Hassan. 


\section{Figures:}

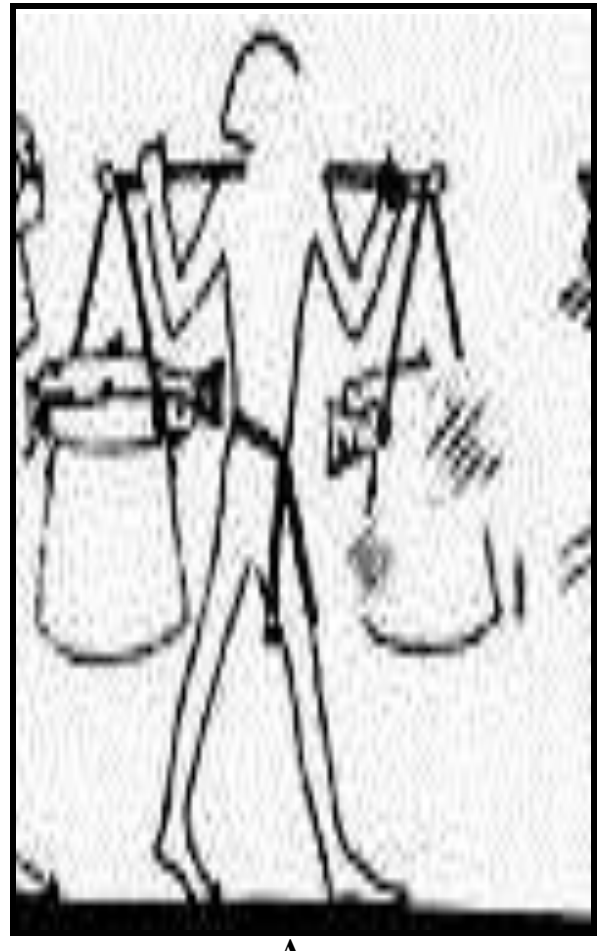

A

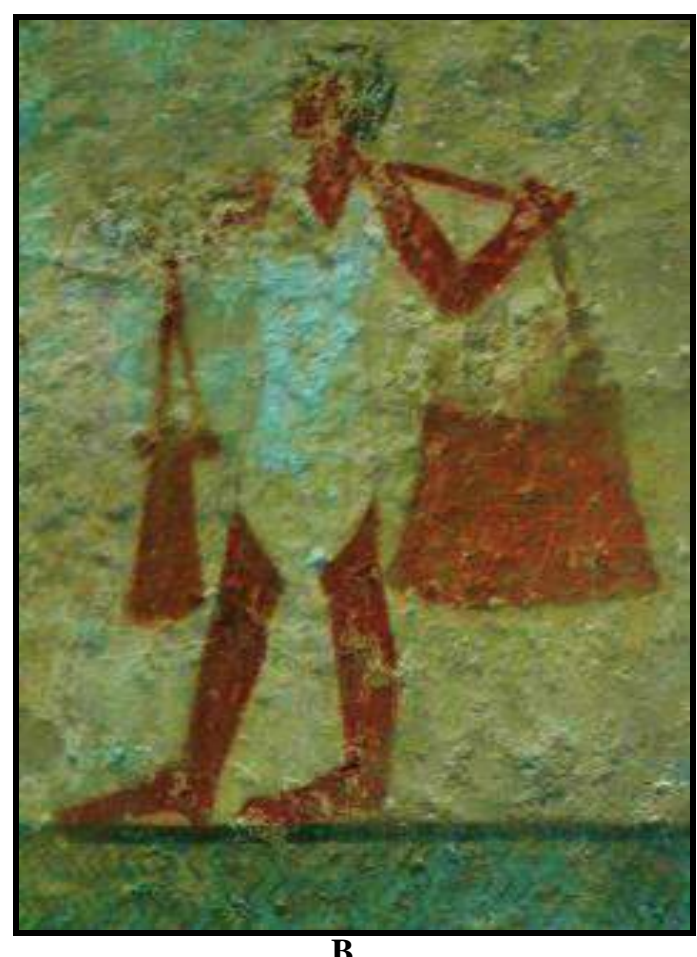

B

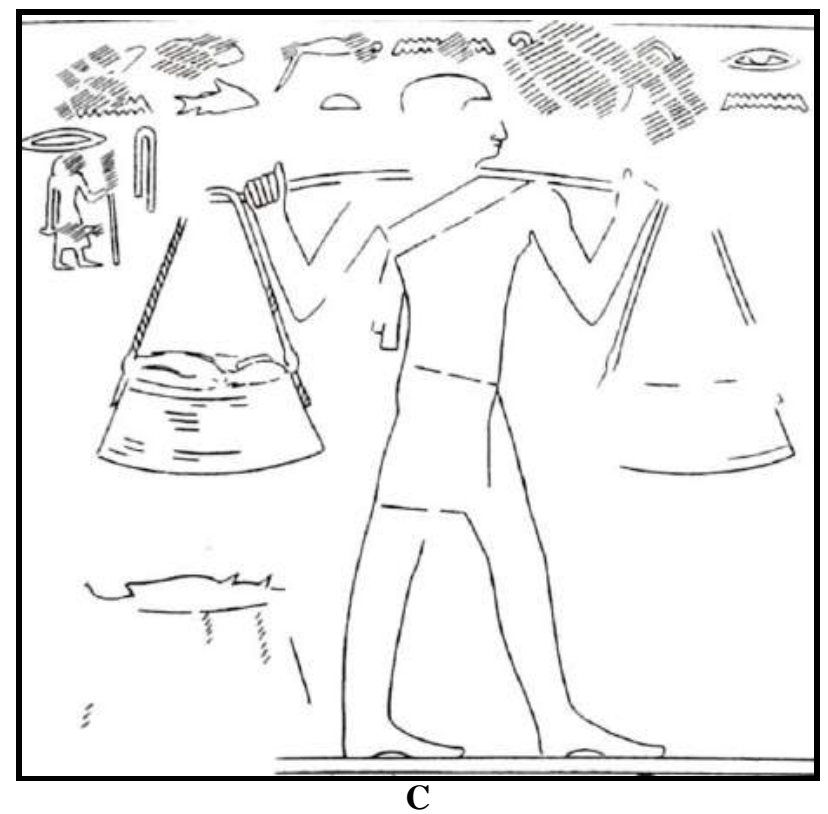

Figure 1: Fish-bearer in Marsh-related activities a. El Bersha, tomb of Djehuty-hotep

(https://www.osirisnet.net/tombes/el bersheh/djehoutyhotep/e djehoutyhotep 02.htm, accessed on 12-15-2018)

b. Beni Hassan, tomb No. 3 of Khnumhotep II (Newberry (1893) I, pl. XXXII) c. Meir, tomb of Ukhhotep III (Blackman (1915 b), pl. 7) 

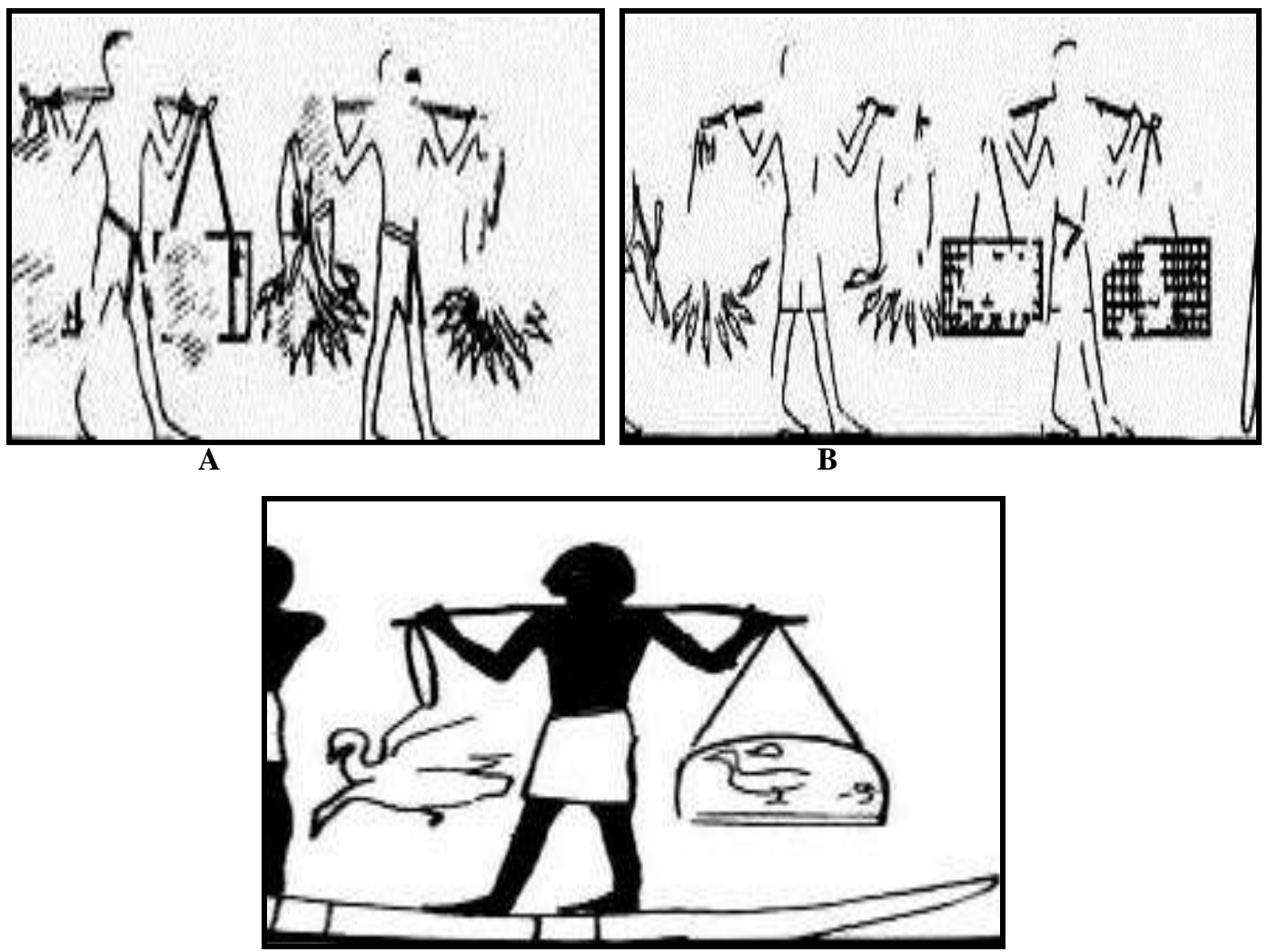

C

Figure 2: Caught marsh birds in cages in Marsh-related activities a. El Bersha, tomb of Djehuty-hotep

(https://www.osirisnet.net/tombes/el bersheh/djehoutyhotep/e djehoutyhotep 02.htm, accessed on 12-20-2018)

b. El Bersha, tomb of Djehuty-hotep

c. Beni Hassan, tomb No. 29 (Newberry (1893) II, pl. XXVIII)
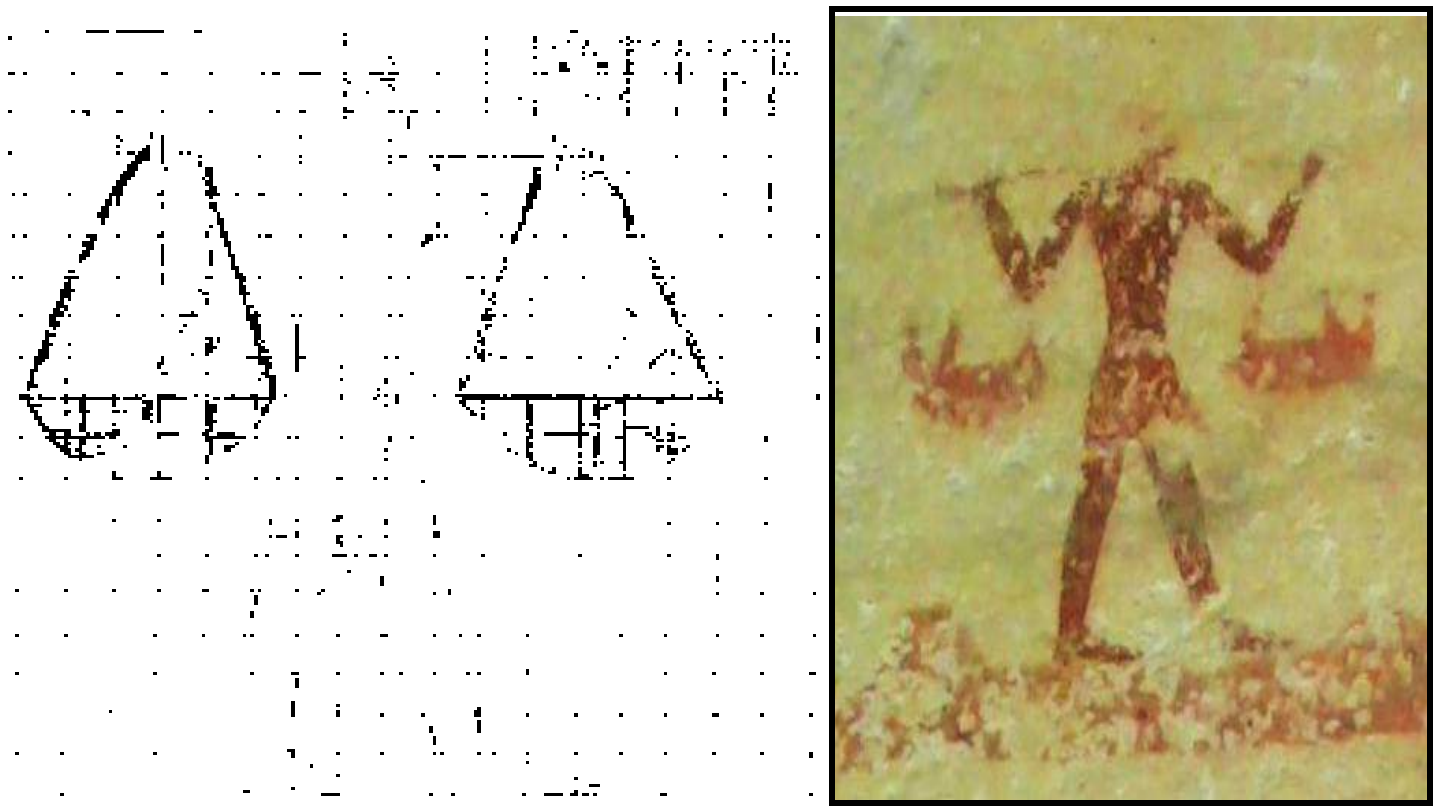

A

B

Figure 3: Hunters returning from the desert with gazelles

a. Meir, tomb of Ukhhotep (Blackman (1915 a), p l. XI)

b. Beni Hassan, tomb of Khety (photographed by the researcher) 

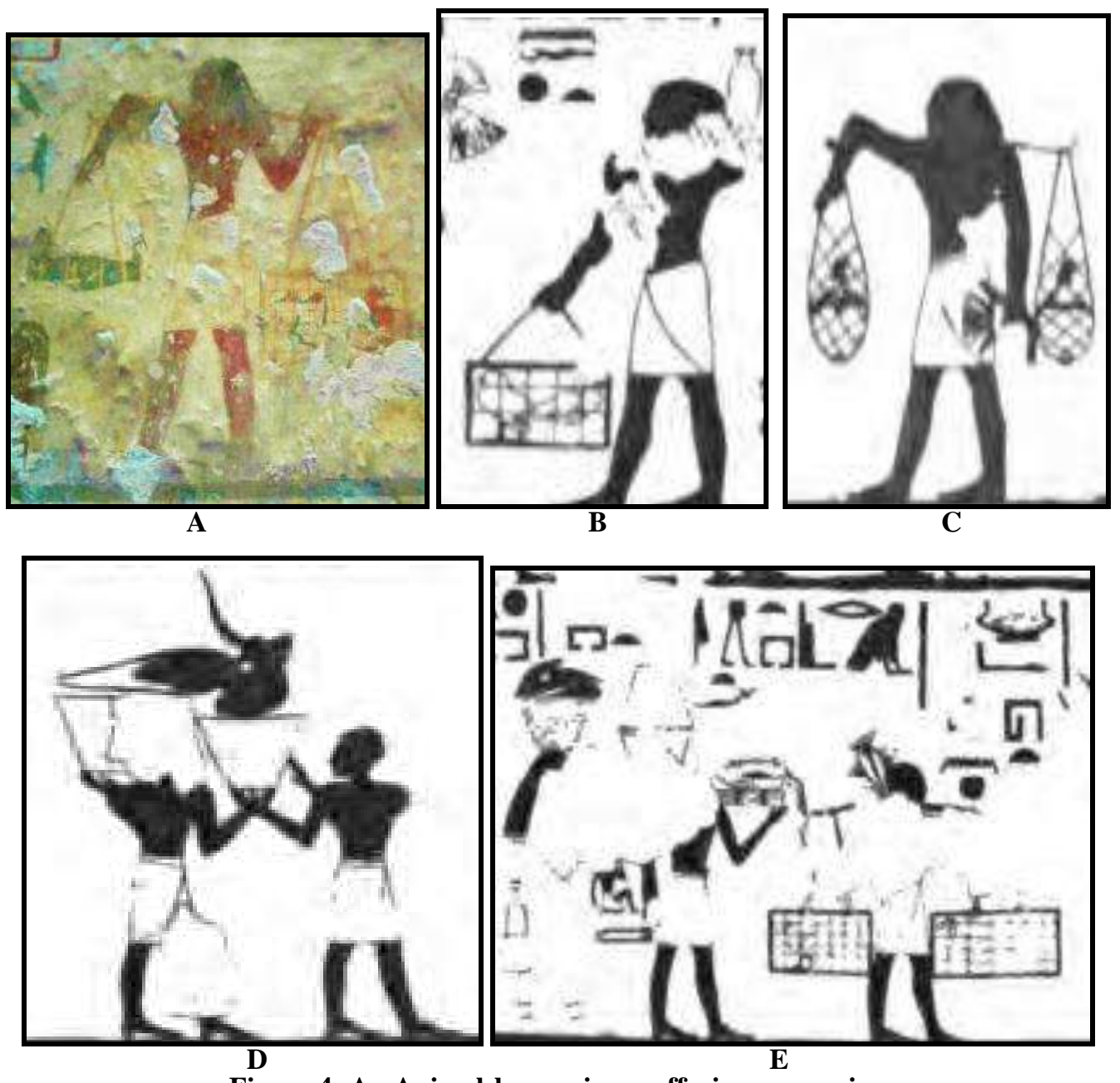

Figure 4: An Animal-bearer in an offering procession

a. , b., c. Beni Hassan, tomb No. 2 of Amenemhat, main chamber, south wall, east end. ((a) photographed by the researcher; Newberry (1893) I, pl. XVII)

d., e. Beni Hassan, tomb No. 2 of Amenemhat, the shrine. (Newberry (1893) I, pls. XIX)
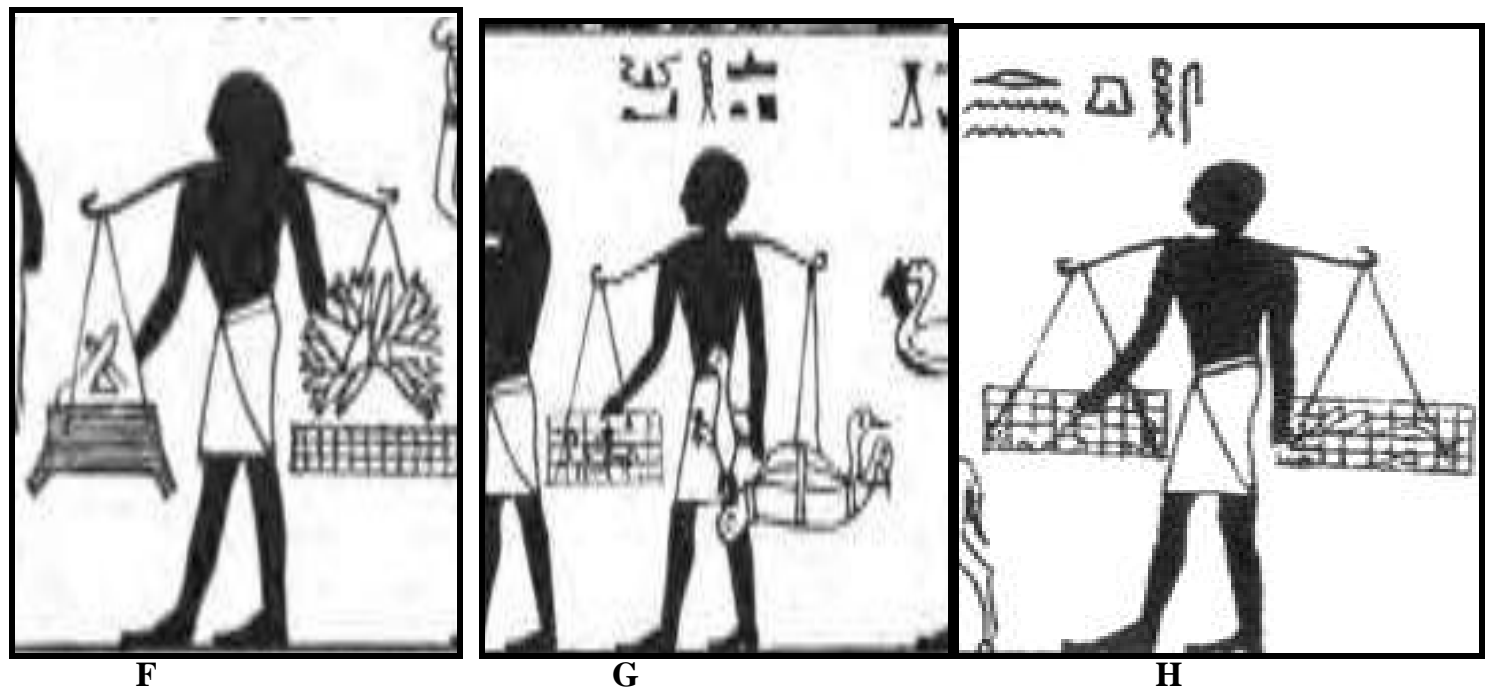

f., g., h., Beni Hassan, tomb No. 3 of Khnumhotep II (Newberry (1893) I, pl. XXXV) 
مناظر حمل سلال الحيوانات بمقابر أفراد الدولة الوسطي

ولاء محمد عبد الحكيم - .سمر مصطفي كمال

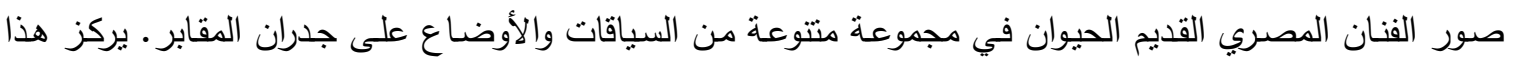

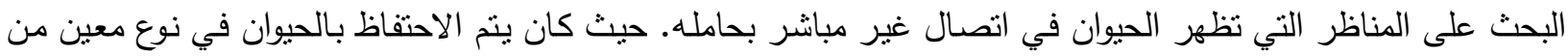

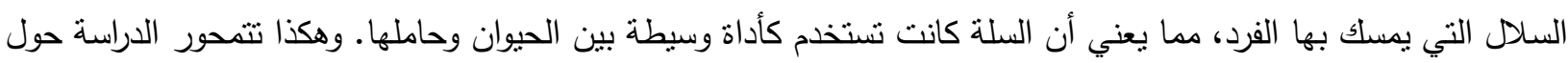

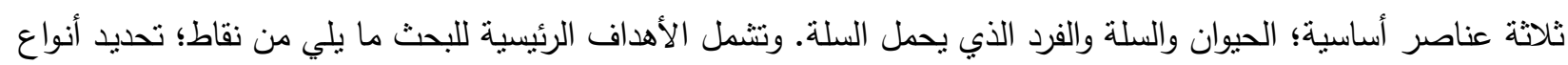
الحيوانات التي كانت تحمل عادة في سلال، توضيح سياق المناظر علي جدران المقابر، تحديد الأشكال الأساسية للسـلال التي كانت تستخدم لحمل الحيوان، وصف التصـوير المجسم لحامل الحيوان. ولتحقيق الهدف من الدراسـة تم استخدام المنهج الوصفي والتحليلي لمناظر مقابر أفراد الدولة الوسطى (بني حسن ، مير ، البرشا ، طيبة). ومن أهم نتائج الدراسة؛ يبلغ عدد مقابر أفراد الدولة الوسطى التي تحوي منظر "حمل سلال الحيوانات "ستة مقابر (أربعة في بني حسن ، وواحد في مير ، وواحد في البرشا(، أما العدد الإجمالي للمناظر هو ستة عشر منظرا لحمل سلال الحيوانات .يوجد أكبر عدد منها في

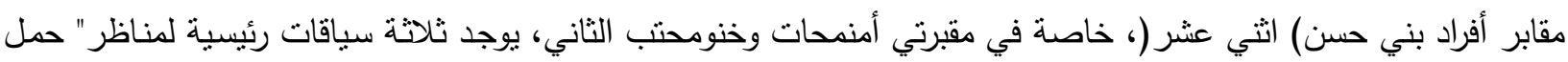

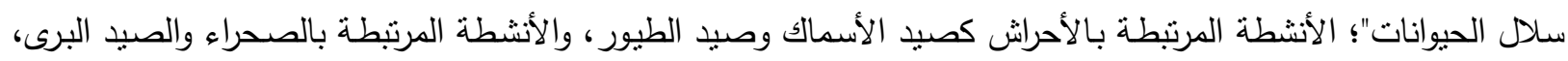
ومواكب تقديم القرابين والتي شملت العدد الأكبر من المناظر، تسعة مناظر توجد فقط في مقابر أفراد بني حسن (مقابر

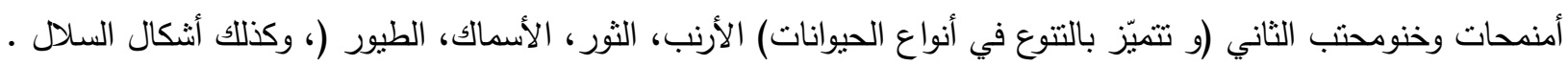

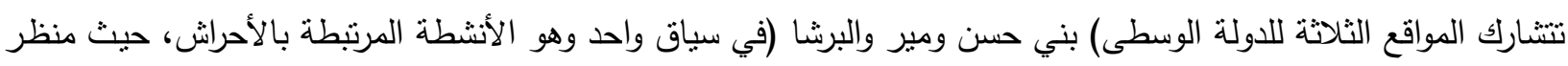

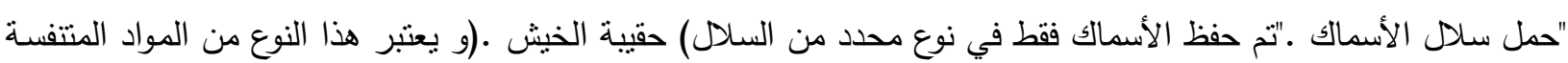
للهواء التي تحافظ على الأسماك من الفساد، ظهر الفرد في كل المناظر حاملا سلتين عن طريق نير يحمل على كتفيه،

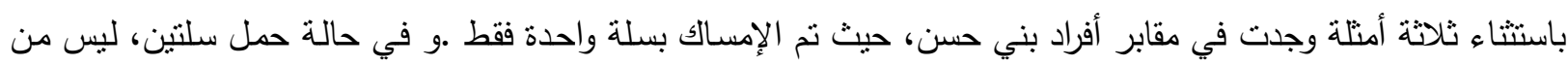

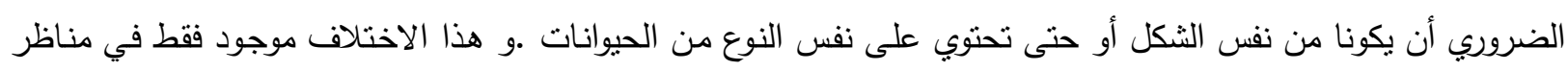

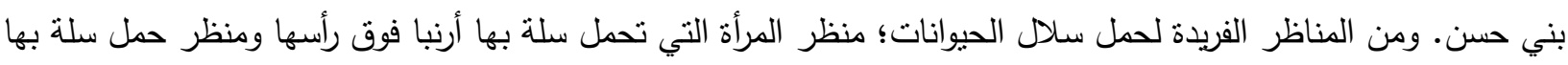
رأس ثور بقرن واحد طويل بمقبرة أمنمحات ببني حسن؛ والمناظر التي تمنل الأنماط الفريدة للسلال التي ظهرت مرة واحدة في مقابر بني حس) سلة على شكل وعاء مقلوب في المقبرة رقم29 ، والسلة الثبكية بمقبرة أمنحات، وسلة على شكل كرسي صغير بلا مسند في بمقبرة خنومحتب الثاني(؛ ومنظر مقبرة ختي ببني حسن حيث حمل سلة الغزال في سياق الأنشطة

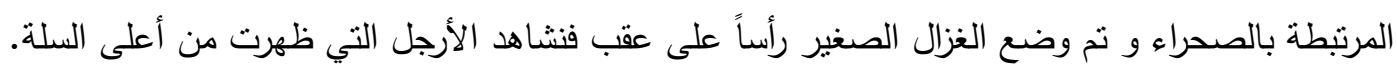
الكلمات المفتاحية: الحيوانات ، السلال ، الدولة الوسطى ، مقابر الأفراد. 


\section{Notes:}

${ }^{1}$ Hidden Voices: Unveiling Women in Ancient Egypt. A Companion to Women in the Ancient World, Szpakowska, K. (2012), pp.25-38, ed. Sharon L. James and Sheila Dillon. Malden, MA; Oxford: Wiley-Blackwell

${ }^{2}$ Merzeban, R.Y. (2014). À propos de quelques analogies iconographiques dans les tombes privées, BIFAO, 114, 339-64.

${ }^{3}$ Egyptian Wall Painting. Tiradritti, F. and Vannini, S. (2008), p.170, English language ed., 1st ed., Abbeville Press, New York

${ }^{4}$ Ibid, p. 171.

${ }^{5}$ Maitland, M. (2018). Dirt, Purity, and Spatial Control: Anthropological Perspectives on Ancient Egyptian Society and Culture during the Middle Kingdom. Journal of Ancient Egyptian Interconnections, 17 (March 2018), 47-72.

${ }^{6}$ Shaheen. A. M. (2007), Water Carrier" or the Like in the Ancient Egyptian Sources and Its Resemblance to Dilmun Glyptic Art. the Archaeology and Art of Ancient Egypt, Essays in Honor of David B. O'Connor, 2, ConseiL Supreme des Antiquites de L'Egypte, Le Caire, 369-80.

${ }^{7}$ Tombs at Giza. Volume I. Kaiemankh (G 4561) and Seshemnefer I (G 4940), Kanawati, N. (2001), p. 31, pls. 7 (a, b), Aris and Phillips, Ltd, Warminster, Wiltshire; The Offering Chapel of Sekhem-ankh-ptah in the Museum of Fine Arts, Simpson, W.K. (1976), pp. 2-3, pl. v [b], figs. 16, 19 [d], Department of Egyptian and Ancient Near Eastern Art, Museum of Fine Arts, Boston; A History of the Giza Necropolis, Reisner, G. A. (1942), p. 322 n. 1, I, Harvard University Press, Cambridge, Massachusetts; Excavations at Gîza 1932-1933, Hassan, S. (1943), pp. 111, 114, 135, figs. 58, 77, IV, Service des Antiquités de l'Égypte, Cairo; The Offering Chapel of Kayemnofret in the Museum of Fine Arts, Simpson, W.K. (1992), pp. 5-6, fig. 6, Department of Egyptian and Ancient Near Eastern Art, Museum of Fine Arts, Boston; Le Tombeau de Ti. Fasc. II [1]. La chapelle. Mémoires publiés par les membres de l'Institute Français d'Archéologie Orientale du Caire, Wild, H. (1953), pl. cxi, LXV, Cairo; The Scepter of Egypt. A Background for the Study of the Egyptian Antiquities in the Metropolitan Museum of Art. Part I. From the Earliest Times to the End of the Middle Kingdom, Hayes, W.C. (1953), pp. 96-7, fig. 54, Harper and Brothers in co-operation with the Metropolitan Museum of Art, New York; The Teti Pyramid at Saqqara. Volume II. The Tomb of Ankhmahor, Kanawati, N. and A. Hassan (1997), p. 38, pl. 43 [a], The Australian Centre for Egyptology: Report 9. Aris and Phillips, Ltd, Warminster, Wiltshire; The Teti Pyramid Cemetery at Saqqara. Volume VI. The Tomb of Nikauisesi, Kanawati, N. and M. Abder-Raziq (2000), pp. 35-6, pls. 8-9, 11, 47, The Australian Centre for Egyptology: Report 14. Aris and Phillips, Ltd, Atlas zur altägyptischen Kulturgeschichte. Teil III, Wreszinski, W. (1936), pp. 213-4, 291, Taf. 98 B, 116 A; Graber des Alten Reiches. J. C. Hinrichs Verlag, Leipzig; The Mastaba of Mereruka. Part I (Chambers A 1-10, Figures 1-103), Duell, P. (1938), pls. 5 B, 10, 13, Oriental Institute Publications (31), University of Chicago Press, Chicago, Illinois; Mereruka and his Family. Part I. The Tomb of Meryteti, Kanawati, N. and M. Abder-Raziq (2004), pp. 22-3, pls. 3, Australian Centre for Egyptology: Report 21. Aris and Phillips, Ltd, Oxford; The Mastaba of Hetep-her-akhti. Study on an Egyptian Tomb Chapel in the Museum of Antiquities, Leiden, Mohr, H.T. (1943), p. 58, fig. 28, Mededeelingen en Verhandelingen No. 5. van het vooraziatisch-egyptisch gezelschap Ex Oriente Lux. E. J. Brill, Leiden; ; Geschichte Aegyptens, Breasted, J. H. (1936), p. 204, Phaidon-Verlag, Zurich; Saqqara. I. The Tomb of Merefnebef, Mysliwiec (2004), p. 145, pls. xxi, lxvi, Polish-Egyptian Archaeological Mission. Éditions Neriton, Warsaw; The Unis Cemetery at Saqqara. Volume II. The Tombs of Iynefert and Ihy (reused by Idut), Kanawati, N. and M. AbderRaziq (2003), p. 20, pl. 39, The Australian Centre for Egyptology: Report 19. Aris and Phillips, Ltd, Oxford; Die Wanddarstellungen im Grab des Mehu in Saqqara. Archäologische Veröffentlichungen 42, Altenmüller, H. (1998), pp. 137-9, Deutsches Archäologisches Institut, Abteilung Kairo. Philipp von Zabern, Mainz-am-Rhein; Der Unas-Friedhof Nord-West. Topographisch-historische Einleitung. 1. Munro, P. (1993), pp. 53, 57, Taf. 10, 12, Das Doppelgrab der Königinnen Nebet und Khenut. Philipp von Zabern, Mainz am Rhein; Saqqara. The Royal Cemetery of Memphis. Excavations and Discoveries since 1850, Lauer, J.P. (1976), pl. 67, Thames and Hudson, Ltd. Charles Scribner's Sons, London and New York; Le Tombeau de Ti. Fasc. II [1]. La chapelle. Mémoires publiés par les membres de l'Institute Français d'Archéologie Orientale du Caire, Ziegler, H. (1993), pp. 82-3, LXV, Cairo; The Tomb of Nefer and Ka-hay. Old Kingdom Tombs at the Causeway of King Unas at Saqqara. Archäologische Veröffentlichungen 5, Moussa, A.M. and H. Altenmüller (1971), p. 21, pls. 1, 4, Deutsches Archäologisches Institut, Abteilung Kairo. Philipp von Zabern, Mainz am Rhein; Das Grab des Nianchchnum und Chnumhotep. Old Kingdom Tombs at the Causeway of King Unas at Saqqara. Archäologisches Veröffentlichungen 21, Moussa, A.M. and H. Altenmüller (1977), p. 96, Taf. 31, Abb. 12, Deutsches Archäologisches Institut, Abteilung Kairo. Philipp von Zabern, Mainz am Rhein; Two Tombs of Craftsmen. Old Kingdom Tombs at the Causeway of King Unas at Saqqara. Archäologische Veröffentlichungen 9, Moussa, A.M. and F. Junge (1975), p. 40, pl. 11, Deutsches Archäologisches Institut, Abteilung Kairo. Philipp von Zabern, Mainz am Rhein; Hieroglyphic Texts from Egyptian Stelae, \&c., in the British Museum (6), Hall, H.R. and E.J. Lambert (1922), p. 6, pl. xii [lower], The Trustees of the British Museum, London; Catalogue général des antiquités égyptiennes du Musée du Caire. Denkmäler des Alten Reiches im Museum von Kairo. Nr. 1295-1808. Teil I. Text und Tafeln zu Nr. 1295-1541, Borchardt, L. (1937), p. 236, Bl. 49 [CG 1535], Reichsdruckerei Berlin, Berlin; Catalogue général des antiquités égyptiennes du Musée du Caire. Denkmäler des Alten Reiches im Museum von Kairo. Nr. 1542-1808. Teil II. Text und Tafeln zu Nr. 1542-1808, Borchardt, L. (1964), pp. 25, 190-1, Bls. 63 [CG. 1562], 103 [CG 1771], Service des Antiquités de l'Égypte; Medum, Petrie, W.M.F. (1892), pp. 24, 38, pl. xii, David Nutt, London; Deshasha. The Tombs of Inti, Shedu and Others. The Australian Centre for Egyptology: Report 5, Kanawati, N. and A. McFarlane(1993), pp. 28-9, pls. 9, 33, Sydney; The Rock Tombs of Deir el-Gebrâwi. Volume I. Tomb of Aba and Smaller Tombs of the Southern Group. Archaeological Survey of Egypt, Eleventh Memoir. Egypt Exploration Fund, Davies, N. de G. (1902), p. 13, pls. iv, xx, xxi, London; The Rock Tombs of Meir. Volume V. The Tomb-chapels A, No. 1 (Ni-ankh-Pepi), A, No. 2 (Pepionkh), A, No. 4, D, No. 1, E, Nos. 1-4. Archaeological Survey of Egypt, Twenty-eighth Memoir. Egypt Exploration Society, Blackman, A.M. and M.R. Apted (1953), p. 32, pls. xxiv, lvii, London; The Rock Tombs of El-Hawawish. The Cemetery of Akhmim. Volume IV, Kanawati, N. (1983), pp. 20-1, pl. 2, fig. 12. The Macquarie Ancient History Association, Sydney; Some Decorated Tombs of the First Intermediate Period at Naga edDêr, Peck, C.N. (1959), p. 5, 77, pl. I, VI, University Microfilms, Department of Egyptology, Brown University, Ann Arbor, Michigan; The Tombs of El-Hagarsa. Volume III. The Australian Centre for Egyptology: Report 7, Kanawati, N. (1995), p. 33, pls. 7 [a], 8, 35, Sydney; Dendereh 1898. Egypt Exploration Fund, Seventeenth Memoir. Egypt Exploration Fund, Petrie, W.M.F. 
(1900), p. 45, pl. v, London; Three Old-Kingdom Tombs at Thebes. I. The Tomb of Unas-Ankh no. 413. II. The Tomb of Khenty no. 405. III. The Tomb of Ihy no. 186. Archäologische Veröffentlichungen 14, Saleh, M. (1977), p. 22, figs. 47-9, 54, Deutsches Archäologisches Institut, Abteilung Kairo. Philipp von Zabern, Mainz am Rhein.

8The Senedjemib Complex. Part I. The Mastabas of Senedjemib Inti (G 2370), Khnumenti (G 2374) and Senedjemib Mehi (G 2378). Giza Mastabas, Volume 7. Art of the Ancient World, Brovarski, E. (2001), p. 144, fig. 114, Museum of Fine Arts, Boston; Tombs at Giza. Volume II. Seshathetep/Heti (G 5150), Nesutnefer (G 4970) and Seshemnefer II (G 5080), Kanawati, N. (2002), p. 58, pl. 62, Australian Centre for Egyptology: Report 18. Aris and Phillips, Ltd, Warminster, Wiltshire; Die altägyptische Grabkammer Seschemnofers III. aus Gîsa, Brunner-Traut, E. (1977), p. 22, Taf. 6, Eine Stiftung des Geheimen Hofrats Dr. h. c. Ernst von Sieglin an die Tübinger Universität. Philipp von Zabern, Mainz; Mastabas of Cemetery G 6000. Including G 6010 (Neferbauptah); G 6020 (Iymery); G 6030 (Ity); G 6040 (Shepseskafankh). Giza Mastabas, Volume 5, Weeks, K.R. (1994), p. 49, fig. 40, pl. 25 [a], Department of Ancient Egyptian, Nubian, and Near Eastern Art, Museum of Fine Arts, Boston; The Mastaba of Queen Mersyankh III. G 7530-7540. Giza Mastabas, Volume I, Dunham, D. and W.K. Simpson (1974), p. 11, pls. iii [a]; Junker (1953), pp. 234-5, abb. 91, Taf. xxiv [a], Department of Egyptian and Ancient Near Eastern Art, Museum of Fine Arts, Boston; Excavations at Gîza 1932-1933. Volume IV, Hassan, S. (1943), pp. 133-4, fig. 76, Service des Antiquités de l'Égypte, Cairo; Simpson (1976), p. 12, pl. D; The Mastaba of Hetep-her-akhti. Study on an Egyptian Tomb Chapel in the Museum of Antiquities Leiden, Mohr, H.T. (1943), p. 53, fig. 24, Mededeelingen en Verhandelingen No. 5. van het vooraziatisch-egyptisch gezelschap Ex Oriente Lux. E. J. Brill, Leiden; The Rock Tombs of Sheikh Saïd. Archaeological Survey of Egypt, Tenth Memoir, Davies, N. de G. (1901), pp. 11-12, pls. iv [upper], v, London; Paget and Pirie (1989), p. 29, pl. xxxii; Kanawati and Abder-Raziq (2003), p. 53, pl. 62; Altenmüller (1998), p. 135, Taf. 34 [b]; La Tombe de Ni-Ankh-Pepi à Zâouyet el-Mayetîn. Mémoires de l'Institut Français du Caire, Tome LXX, Varille, A. (1938), p. 10, fig. 3, . Institut Français d'Archéologie Orientale, Cairo; Davies (1901), pp. 23-4, pl. xii; The Rock Tombs of Deir el-Gebrâwi. Volume I. Tomb of Aba and Smaller Tombs of the Southern Group. Archaeological Survey of Egypt, Eleventh Memoir. Davies, N. de G. (1902), p. 26, pl. xx, Egypt Exploration Fund, London; The Old Kingdom Tombs of El-Hammamiya, El-Khouli, A. and N. Kanawati (1990), p. 74, pl. 73 [a], The Australian Centre for Egyptology: Report 2, Sydney; The Rock Tombs of El Hawawish. The Cemetery of Akhmim. Volume VII, Kanawati, N. (1987), p. 41, fig. 30, The Ancient History Documentary Research Centre, Sydney.

${ }^{9}$ A Cemetery of Palace Attendants. Including G 2084-2099, G $2230+2231$, and G 2240. Giza Mastabas, Volume 6, Roth, A.M. (1995), p. 132, pls. 96 [a, b], 97 [b], 189, Department of Ancient Egyptian, Nubian, and Near Eastern Art, Museum of Fine Arts, Boston; Gîza. Band XI. Der Friedhof südlich der Cheopspyramide. Östteil, Junker, H. (1953), pp. 235-7, Abb. 92, Österreichische Akademie der Wissenschaften. Rudolph M. Rohrer, Wien; Le Tombeau de Ti. Fasc. II [1], Wild, H. (1953), pl. cxxviii, La chapelle. Mémoires publiés par les membres de l'Institute Français d'Archéologie Orientale du Caire, Tome LXV, Cairo; Saqqâra Tombs. Volume I. The Mastabas of Mereri and Wernu. Archaeological Survey of Egypt, Thirty-sixth Memoir, Davies, W.V., A. El-Khouli , A.B. Lloyd and A.J. Spencer (1984), p. 29, pl. 31, Archaeological Survey of Egypt, Thirty-sixth Memoir. Egypt Exploration Society, London; The Tomb of Ptah-hetep. In the Ramesseum by J. E. Quibell. Egyptian Research Account, Second Memoir, Paget, R.F.E. and A.A. Pirie (1989), pp. 29-30, pl. xxxiii, Histories and Mysteries of Man, Ltd, London; The Tombs of Nefermaat and Rahotep at Maidum. Discovery, Destruction and Reconstruction. Egyptian Tombs of the Old Kingdom. Volume One, Harpur, Y.M. (2001), pp. 77, 79, fig. 80, pls. 11-12, Oxford Expedition to Egypt, Oxford; Davies,N. de G. (1902), p. 9, pl. ix; The Old Kingdom Cemetery at Hamra Dom (el-Qasr wa es-Saiyad), Säve-Söderbergh, T. (1994), p. 44, pls. 18 [a, b], 62 [a], The Royal Academy of Letters, History and Antiquities, Stockholm.

${ }^{10}$ Beni Hasan, Part I, Newberry, P.E. (1893), pl. XXXII; The Rock Tombs of Meir II, Blackman, A.M. (1915b), pl. 7, Egypt Exploration Fund, London; https://www.osirisnet.net/tombes/el_bersheh/djehoutyhotep/e_djehoutyhotep_02.htm, (accessed on

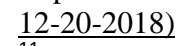

${ }^{11}$ Beni Hasan, Part I, Newberry, P.E. (1893)II, pl. XXVIII.

https://www.osirisnet.net/tombes/el_bersheh/djehoutyhotep/e_djehoutyhotep_02.htm, (accessed on 12-18-2018.

${ }_{12}$ Blackman (1915 a), p 1. XI; Newberry (1893)II, pl. XIII.

${ }^{13}$ Newberry, P.E. (1893)I, pls. XVII, XIX, XXXV; Art and Daily Life in an Egyptian Province, Kanawati, N. and Woods A. (2010), p. 25, Supreme Cuncil of Antiquities Press, Cairo.

${ }^{14}$ Brémont, A. (2018) Into the Wild? Rethinking the Dynastic conception of the Desert beyond Nature and Culture. Journal of Ancient Egyptian Interconnections, 17, 1-17.

${ }^{15}$ Khalil, H. and El Kenawy, M. (2014) Highlight of Comparison between The Gazelle Behaviour in the Natural Environment and in the Ancient Egyptian Scenes. Egyptian Journal of Archaeological and Restoration Studies (EJARS), June 4. Issue 1, 77-84.

${ }^{16}$ The Gazelle in Ancient Egyptian Art Image and Meaning, Uppsala Studies in Egyptology 6, Strandberg, A. (2009), fig. 59, p. 122, Department of Archaeology and Ancient History, Uppsala University.

${ }^{17}$ Blackman (1915 a), p 1. XI.

${ }^{18}$ Newberry (1893)II, pl. XIII.

${ }^{19}$ A Field Guide to the Mammals of Egypt, Hoath, R. (2003), pp. 218- 9, Cairo/New York, American University in Cairo Press.

${ }^{20}$ McClintock, J. and Strong, J. Hare. (1894) Cyclopaedia of Biblical, Theological, and Ecclesiastical Literature, 4, New York, Harper and Brothers Publishers, 72-3.

${ }^{21}$ Newberry (1893)I, pl. XIX.

${ }^{22}$ Ibid, pl. XXXV.

${ }^{23}$ Ibid, pl. XIX.

${ }^{24}$ Elsaeed, E., and Khalifa, H. (2016). A Comparative Study of Modified Animal Horns in Ancient Egypt and Modern African Tribes. Cultural and Linguistic Transition explored. Proceedings of the ATrA closing workshop Trieste, May 25-26, 166-87.

${ }^{25}$ The Birds of Ancient Egypt, Houlihan, P.F. (1988), pp. 69-70, the American University in Cairo Press, Cairo.

${ }^{26}$ Ibid, pp. 71-2.

عبد الغفار شديد (2016 الطبعة الأولي)، المركز القومي للترجمة، القاهرة، شكل رقم 150، ص 
${ }^{28}$ Newberry, (1893), I, pl. XVII.

${ }^{29}$ Sahrhage, D. (2008). Fishing in Ancient Egypt, Encyclopedia of the History of Science, Technology and Medicine in NonWestern Cultures, Springer, the Netherlands, 922-7.

${ }^{30}$ The Oryx Nome: an Egyptian Cultural Landscape of the Middle Kingdom, Graves, C. (2017), p. 280, A thesis submitted to the University of Birmingham for the degree of Doctor of Philosophy, Department of Classics, Ancient History, and Archaeology, School of History and Cultures, College of Arts and Law, University of Birmingham.

${ }^{31}$ The fish species are recognized here by comparing the way of their representation in the theme that shows the proportions of the body, the fin, and tail by the various fish species found on the wall picture in the mastaba of Mereruka at Saqqara. Blackman (1915 b), pl. 7; Sahrhage (2008), p. 924, Fig. 5.

${ }^{32}$ https://www.osirisnet.net/tombes/el_bersheh/djehoutyhotep/e_djehoutyhotep_02.htm, accessed on 12-18-2018.

${ }^{33}$ Newberry (1893) I, pl. XXXII.

${ }^{34}$ Sahrhage (2008), p. 927.

${ }^{35}$ The basketry includes other objects like bags, mats, sieves, pot stands, nets, brushes, brooms, boxes, furniture, and sandals. Ancient Egyptian Materials and Technology, Shaw, I and P.T. Nicholson (2000), p. 254, Cambridge University Press.

${ }^{36}$ McClintock (1894), p. 602.

${ }^{37}$ Newberry (1893) I, pls. XVII, XXXV.

${ }^{38} \mathrm{Ibid}$, pls. XIX, XXXV; https://www.osirisnet.net/tombes/el_bersheh/djehoutyhotep/e_djehoutyhotep_02.htm, accessed on 12$10-2018$.

${ }^{39}$ Newberry (1893) II, pl. XXVIII.

${ }^{40}$ Newberry (1893) I, pl. XVII.

${ }^{41}$ Ibid, pl. XIX.

${ }^{42}$ Blackman (1915a), pl. XI.

${ }^{43}$ Newberry (1893) I, pl. XXXII; Blackman (1915 b), pl. 7;

https://www.osirisnet.net/tombes/el bersheh/djehoutyhotep/e djehoutyhotep 02.htm, accessed on 12-20-2018.

${ }^{44}$ Newberry (1893) I, pl. XXXV.

${ }^{45}$ Shaheen (2007), p. 372.

${ }^{46}$ Newberry (1893) I, pl. XXXV.

${ }^{47} \mathrm{Ibid}$, pl. XVII; https://www.osirisnet.net/tombes/el_bersheh/djehoutyhotep/e_djehoutyhotep_02.htm, accessed on 12-15-2018.

${ }^{48}$ Blackman (1915 b), pl. 7.

${ }^{49}$ Newberry (1893) II, pl. XXVIII.

${ }^{50}$ Newberry (1893) I, pl. XIX.

${ }^{51}$ Beni Hassan, tomb No. 29, main chamber, north wall, west end, second upper register. Newberry (1893) II, pl. XXVIII); Meir, tomb of Ukhhotep, hall, north wall; Beni Hassan, tomb No. 17 of Khety. Blackman (1915a), pl. XI).

${ }^{52}$ Kanawati, N. and Woods (2010), p. 25.

${ }^{53}$ Beni Hassan, tomb No. 2 of Amenemhat, main chamber, south wall, east end; Newberry (1893)I, pl. XVII).

${ }^{54}$ Tomb No. 3 of Khnumhotep II; Newberry (1893) I, pl. XXXV.

${ }^{55}$ Newberry (1893 )I, pl. XIX.

${ }^{56}$ Ibid, pl. XVII.

${ }^{57}$ Ibid, pl. XIX.

${ }^{58}$ Simpson (1988), p. 203.

${ }^{59}$ Blackman (1915 a), p 1. XI.

${ }^{60}$ https://www.osirisnet.net/tombes/el_bersheh/djehoutyhotep/e_djehoutyhotep_02.htm, accessed on 12-15-2018.

${ }^{61}$ Maitland (2018), fig. 6, p. 53.

${ }^{62}$ Newberry (1893) I, pl. XXXII. 